\title{
Recommended Practices for Managing Large, Multi-Site Engineering Edu- cation Research Data Collection Projects
}

\section{Dr. Maura J. Borrego, University of Texas - Austin}

Maura Borrego is Associate Professor of Mechanical Engineering and Curriculum \& Instruction at the University of Texas at Austin. She previously served as a Program Director at the National Science Foundation and an associate dean and director of interdisciplinary graduate programs. Her research awards include U.S. Presidential Early Career Award for Scientists and Engineers (PECASE), a National Science Foundation CAREER award, and two outstanding publication awards from the American Educational Research Association for her journal articles. Dr. Borrego is Deputy Editor for Journal of Engineering Education and serves on the board of the American Society for Engineering Education as Chair of Professional Interest Council IV. All of Dr. Borrego's degrees are in Materials Science and Engineering. Her M.S. and Ph.D. are from Stanford University, and her B.S. is from University of Wisconsin-Madison.

\section{Dr. Mary E. Besterfield-Sacre, University of Pittsburgh}

Dr. Mary Besterfield-Sacre is an Associate Professor and Fulton C. Noss Faculty Fellow in Industrial Engineering at the University of Pittsburgh. She is the Director for the Engineering Education Research Center (EERC) in the Swanson School of Engineering, and serves as a Center Associate for the Learning Research and Development Center. Her principal research is in engineering education assessment, which has been funded by the NSF, Department of Ed, Sloan, EIF, and NCIIA. Dr. Sacre's current research focuses on three distinct but highly correlated areas - innovative design and entrepreneurship, engineering modeling, and global competency in engineering. She is currently associate editor for the AEE Journal.

\section{Dr. Cynthia J. Finelli, University of Michigan}

Dr. Cynthia Finelli is Associate Professor of Electrical Engineering \& Computer Science, Research Associate Professor of Education, and Founding Director of the Center for Research on Learning and Teaching in Engineering at the University of Michigan. Her research areas include student resistance to active learning, faculty adoption of evidence-based teaching practices, the impact of classroom space on learning and teaching, and institutional change. She is a fellow in the American Society of Engineering Education, an Associate Editor of the IEEE Transactions on Education, and past chair of the Educational Research and Methods Division of ASEE.

\section{Dr. Lisa R. Lattuca, University of Michigan}

Lisa Lattuca, Professor of Higher Education at the University of Michigan, studies curriculum, teaching, and learning in college and university settings. She examines processes of curriculum development and revision at the course, program, and institutional levels, including how faculty attitudes, beliefs, and cultures influence curricular and instructional practices and how these in affect student learning. In recent years, she has been studying these topics in undergraduate engineering programs with funding from the National Science Foundation.

\section{Mr. Prateek Shekhar, University of Texas - Austin}

Prateek Shekhar is a doctoral candidate in the Department of Mechanical Engineering at The University of Texas at Austin. His research is focused on the adoption of research based curriculum and instructional strategies in engineering classrooms. He holds a M.S. in Electrical Engineering from University of Southern California and B.S. in Electronics and Communication Engineering from India. 


\title{
Recommended Practices for Managing Large, Multi-Site Engineering Education Research Data Collection Projects
}

\begin{abstract}
This is an evidence-based practice paper, intended to share a range of experiences managing data collection across multiple sites and offer recommendations for success. To address some of the broadest and most critical research questions, engineering education researchers are proposing more and more studies of engineering students, faculty, and/or administrators at multiple higher education institutions. Although some information about how to solicit participation from these institutions is shared through papers and presentations disseminating the activities, most of the best practices and accumulated wisdom about how to manage data collection across multiple sites is not widely shared. To remedy this, the authors synthesize their many years' experience coordinating data collection for engineering education research projects and address site selection, local contacts, recruiting, collaboration agreements, and IRB coordination.
\end{abstract}

\section{Introduction}

There are a variety of reasons why collecting research data at multiple institutions or across multiple programs can strengthen a study in engineering education or a related field. Perhaps the most commonly cited reason is that it increases the generalizability or transferability of the findings to different types of institutions or programs, which employ different faculty members and serve different populations of students. Further, conducting multi-site studies can yield substantial databases that lead to better statistical and modeling analyses. With careful sampling procedures, researchers can more easily extend the results of their multi-site studies across a large population or can claim the findings to be generalizable and broadly relevant. Collecting research data from multiple settings increases the chances that the full range of relevant issues and factors is uncovered and the common alternative explanations are considered, especially given the complex nature of engineering education and the extent to which educational interventions rarely meet the needs of all students. Depending on the level of engagement with the sites (which may be extensive in the case of qualitative or site visit approaches), a multi-site design can prompt researchers to write implications and recommendations that are relevant across a wider range of local settings. Conducting studies across multiple sites allows educators and researchers to understand the conditions under which interventions are most likely to positively impact students.

When multi-site studies are published in the peer-reviewed literature, certain details related to arranging for and managing the sites are often overlooked or removed for space considerations. Tradeoffs and failed negotiations are rarely mentioned. In the most recent year of the Journal of Engineering Education, there are six multi-site studies ${ }^{1-6}$, none of which describe their procedures for coordinating data collection beyond the rationale underlying the sampling of sites. Although researchers who have invested several years in a particular multi-site study or who have conducted several such studies have the benefit of hindsight, this situation does not provide much learning in the broader field or among novice researchers planning their first multiinstitutional and collaborative study. 
Learning among engineering education researchers about designing and conducting multi-site studies is vitally important because such studies are considered by many to be more competitive for National Science Foundation engineering education funding than single site studies (all other aspects being equal). This prompts a great many researchers to design and propose multi-site studies, sometimes frantically arranging access in the few days before a proposal deadline. Since proposals are confidential, they are reviewed by a small number of peer reviewers who provide feedback on many aspects of the entire proposal, resulting in at most a few sentences about the multi-site design in a long feedback loop spanning at least six months.

Whether or not the actual number of multi-site engineering education studies being proposed and executed is actually increasing, it can be argued that the field has developed a long enough history to support more detailed discussions of methods specific to planning and executing successful multi-site research studies in higher education settings.

The goal in this paper is to share experiences and advice to begin a broader discussion in the field about multi-site research studies in engineering education. The focus is on studies of undergraduate and graduate students, faculty and administrators. This paper discusses the issues, considerations, and tradeoffs involved in planning and executing multi-site engineering education research studies.

\section{Methods}

To prepare this paper, one researcher (author 1) distributed a set of questions to which the first four authors responded. The fifth author drafted the results based on a simple thematic analysis of the responses. All authors were involved in refining explanations and editing the final paper. The authors are experienced with large, multi-institutional engineering education research studies ranging from four to 40 institutions on a wide spectrum of engineering education research areas. The questions targeted several topics pertaining data collection such as site selection, identification of local contacts, recruiting, collaboration agreements, and IRB coordination. The questions are provided in Figure 1. The studies which informed the responses are listed in Table 1.

\section{Findings}

\section{Sampling and selection of sites}

Sampling and selection of sites is an important first step for multi-site studies. While some studies used stratified random sampling to select institutions, most of the studies included in this paper followed a two-step process to select sites. The first step involved creating a short list of potential sites based on the goals of the study. For example, in a study of entrepreneurship programs, the investigators reviewed course catalogs and performed cluster analysis to determine sites that offered desired course attributes. In another study, statistical analysis of existing data was used to identify institutions that outperformed others in graduation rates and production of women and underrepresented minority graduates for in-depth case studies. In other studies, the researchers used simpler approaches such as relying on Carnegie classifications to stratify a sample of institutions across types (i.e., research intensive/extensive, doctoral, master’s, 
baccalaureate) and to maximize diversity (i.e., by including some minority-serving institutions and/or community colleges). The list of ABET-accredited undergraduate programs was a common starting point for creating an initial list of potential institutions.

1. Overview: What is the size/scope of multi-institution data collection projects have you done (and are basing your answers on)? What were the numbers of institutions, participants or departments involved?

2. Sampling and Site Selection: Other than generalizability/transferability concerns, what other considerations to you balance in selecting study sites, e.g., collaborators/contacts, IRB office, prior experience?

3. Contacts: Who do you contact (first) at a prospective study site and why? What considerations do you take into account, e.g., administrative positions, access to participants, IRB training or education research experience?

4. Incentives and Collaboration Agreements: What arguments, commitments, or promises do you offer to prospective sites to encourage their participation, e.g., site reports, Co-PI or coauthor opportunities, funding?

5. Participant Recruitment: Do you rely on local contacts to recruit participants? What are some of your most effective strategies for recruiting participants? How does this vary for survey or interview studies if you have done both?

6. Human Subjects Consent: How do you manage Internal Review Board (IRB) approvals/applications? Do you contact IRB offices directly or through a local IRB PI?

7. Response Rate: What are some of your most effective strategies for maximizing individual response rates? Do you offer incentives, and if so, what type? Are there particular strategies for situations in which you are relying on local contacts to forward email invitations? What are the considerations for paper vs. electronic surveys?

8. Comments: What other advice do you have about communication or any other aspects of the issues raised in these questions?

Figure 1. Questions Typically Considered When Conducting a Multi-Institutional Study

In studies that did not rely on random sampling, the researchers refined their lists based on the availability of known contacts at the target institutions. These known contacts were either administrators who provided access to subjects or engineering education researchers who assisted with IRB paperwork, or both. In some cases, for example those using random sampling, known contacts were not available, and the researchers contacted relatively unknown gatekeepers based on their position as an administrator or program director overseeing a program of interest. Finalizing the list was often an iterative process between representative institution types and known contacts or other access to the sites. 
Table 1. Recent Studies Used to Create the Recommendations

\begin{tabular}{|c|c|c|c|c|c|}
\hline $\begin{array}{l}\text { Study } \\
\text { year }\end{array}$ & Target population & $\begin{array}{l}\text { Number } \\
\text { of sites } \\
\text { involved }\end{array}$ & $\begin{array}{l}\text { Type of data } \\
\text { collected }\end{array}$ & 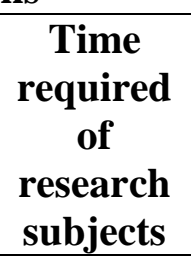 & $\begin{array}{c}\text { Subject } \\
\text { incentives }\end{array}$ \\
\hline Current $^{7}$ & $\begin{array}{l}\text { Freshmen and senior } \\
\text { engineering students } \\
\text { with and without } \\
\text { international } \\
\text { experience }\end{array}$ & 14 & $\begin{array}{l}\text { Closed form } \\
\text { questionnaire }\end{array}$ & 8 minutes & $\begin{array}{l}\text { Gift cards and } \\
\text { monetary } \\
\text { stipend for on- } \\
\text { site organizer }\end{array}$ \\
\hline Current $^{8}$ & $\begin{array}{c}\text { Engineering } \\
\text { instructors and their } \\
\text { undergraduate } \\
\text { students } \\
\end{array}$ & 20 & $\begin{array}{l}3 \text { Closed form } \\
\text { questionnaires }\end{array}$ & $\begin{array}{c}30 \\
\text { minutes } \\
\text { total }\end{array}$ & $\begin{array}{l}\text { Monetary } \\
\text { incentive for } \\
\text { instructor }\end{array}$ \\
\hline $2012^{9}$ & $\begin{array}{c}\text { Engineering } \\
\text { undergraduates }\end{array}$ & 3 & $\begin{array}{c}\text { Closed-form } \\
\text { questionnaire }\end{array}$ & $\begin{array}{l}15 \text { to } 30 \\
\text { minutes }\end{array}$ & $\begin{array}{c}\text { Monetary } \\
\text { stipend }\end{array}$ \\
\hline $\begin{array}{l}2012^{10,} \\
11\end{array}$ & $\begin{array}{c}\text { Undergraduate } \\
\text { students, faculty, } \\
\text { and administrators }\end{array}$ & 18 & $\begin{array}{l}\text { Interviews and } \\
\text { focus groups }\end{array}$ & $\begin{array}{c}90 \\
\text { minutes }\end{array}$ & $\begin{array}{c}\text { Food at focus } \\
\text { groups and site } \\
\text { reports }\end{array}$ \\
\hline $2012^{12}$ & $\begin{array}{c}\text { Engineering } \\
\text { undergraduates }\end{array}$ & 18 & $\begin{array}{l}\text { Closed-form } \\
\text { questionnaire }\end{array}$ & $\begin{array}{c}60 \\
\text { minutes }\end{array}$ & Gift cards \\
\hline $2012^{13}$ & $\begin{array}{l}\text { Engineering students } \\
\text { studying } \\
\text { entrepreneurship }\end{array}$ & 13 & $\begin{array}{l}\text { Closed form } \\
\text { questionnaire }\end{array}$ & $\begin{array}{c}15 \\
\text { minutes }\end{array}$ & None \\
\hline $2012^{14}$ & $\begin{array}{l}\text { Faculty teaching } \\
\text { entrepreneurship to } \\
\text { engineering students }\end{array}$ & 25 & $\begin{array}{l}\text { Open and } \\
\text { closed form } \\
\text { questionnaire }\end{array}$ & $\begin{array}{c}40 \\
\text { minutes }\end{array}$ & $\begin{array}{l}\text { Monetary } \\
\text { stipend }\end{array}$ \\
\hline $2010^{15}$ & $\begin{array}{c}\text { Engineering } \\
\text { departments that } \\
\text { reviewed a white } \\
\text { paper }\end{array}$ & 110 & $\begin{array}{l}\text { Open and } \\
\text { closed form } \\
\text { questionnaire }\end{array}$ & $\sim 2$ hours & None \\
\hline $\begin{array}{l}2010^{16,} \\
17\end{array}$ & $\begin{array}{c}\text { Engineering } \\
\text { undergraduate and } \\
\text { graduate students }\end{array}$ & 4 & $\begin{array}{l}\text { Open and } \\
\text { closed form } \\
\text { questionnaire }\end{array}$ & $\begin{array}{c}20 \\
\text { minutes }\end{array}$ & $\begin{array}{l}\text { Gift cards and } \\
\text { monetary } \\
\text { stipend for site } \\
\text { coordinator }\end{array}$ \\
\hline $2010^{18}$ & $\begin{array}{c}\text { Engineering } \\
\text { instructors and } \\
\text { administrators in } \\
\text { specific departments }\end{array}$ & 6 & Interviews & 1 hour & $\begin{array}{l}\text { Monetary } \\
\text { stipend for site } \\
\text { coordinator }\end{array}$ \\
\hline $2009^{19}$ & $\begin{array}{l}\text { Graduate students, } \\
\text { faculty and } \\
\text { administrators } \\
\text { involved in } \\
\text { interdisciplinary } \\
\text { graduate programs }\end{array}$ & 4 & $\begin{array}{c}\text { Interviews, } \\
\text { focus groups } \\
\text { and } \\
\text { observations }\end{array}$ & 1 hour & $\begin{array}{l}\text { Gift cards and } \\
\text { monetary } \\
\text { stipend for on- } \\
\text { site organizer }\end{array}$ \\
\hline
\end{tabular}




\begin{tabular}{|c|c|c|c|c|c|}
\hline $\begin{array}{c}\text { Study } \\
\text { year }\end{array}$ & Target population & $\begin{array}{c}\text { Number } \\
\text { of sites } \\
\text { involved }\end{array}$ & $\begin{array}{c}\text { Type of data } \\
\text { collected }\end{array}$ & $\begin{array}{c}\text { Time } \\
\text { required } \\
\text { of } \\
\text { research } \\
\text { subjects }\end{array}$ & $\begin{array}{c}\text { Subject } \\
\text { incentives }\end{array}$ \\
\hline $\begin{array}{c}2008^{20,} \\
21\end{array}$ & $\begin{array}{c}\text { Undergraduates, } \\
\text { alumni, faculty, } \\
\text { program heads, } \\
\text { associate deans }\end{array}$ & 30 & $\begin{array}{c}\text { Closed-form } \\
\text { questionnaire }\end{array}$ & $\begin{array}{c}15 \text { to } 30 \\
\text { minutes }\end{array}$ & $\begin{array}{c}\text { Reports and } \\
\text { data to } \\
\text { engineering } \\
\text { school }\end{array}$ \\
\hline $2006^{22,}$ & $\begin{array}{c}\text { Undergraduates, } \\
\text { alumni, faculty, and } \\
\text { program heads }\end{array}$ & 40 & $\begin{array}{c}\text { Closed-form } \\
\text { questionnaire }\end{array}$ & $\begin{array}{c}15 \text { to } 30 \\
\text { minutes }\end{array}$ & None \\
\hline $2006^{24}$ & $\begin{array}{c}\text { Undergraduates in } \\
\text { engineering and } \\
\text { other majors }\end{array}$ & 11 & $\begin{array}{c}\text { Closed-form } \\
\text { questionnaire }\end{array}$ & $\begin{array}{c}60 \\
\text { minutes }\end{array}$ & None \\
\hline $1997^{25}$ & $\begin{array}{c}\text { Freshmen } \\
\text { engineering students }\end{array}$ & 18 & $\begin{array}{c}\text { Closed form } \\
\text { questionnaire }\end{array}$ & $\begin{array}{c}<10 \\
\text { minutes }\end{array}$ & Reports \\
\hline
\end{tabular}

In terms of ease of access, researchers sometimes expressed different preferences based on institution type. One preferred research-focused over teaching-oriented institutions due to faster turn-around time for IRB approval in research institutions. Another noted that some institutions are willing to accept the IRB approval of the investigator's home institution, which can speed the approval process. Another researcher preferred sites with fewer engineering education researchers vying for the attention of over-studied students or having to negotiate with protective gatekeepers. While there are typically more engineering education researchers at research institutions, this is not always the case; and there are several research extensive institutions with few active engineering education researchers. To some extent, there is a tradeoff between availability of known contacts and access to untapped populations of engineering students and faculty. Regardless of the strategy, recruitment of institutions can be a months-long process, and the duration and intensity of the effort should not be underestimated.

Thus, while most multi-institutional studies describe a sampling frame based on institution types, student populations, geographic distribution, and a mix of public and private institutions, the very practical consideration of negotiating access comes into play. Most researchers involved in this effort approached known contacts at familiar institutions. The next section further elaborates considerations taken into account for identifying the primary contact person at the study site.

\section{Contact person at a study site}

In most cases, researchers relied on their known contacts and/or gatekeepers at the study site.

The known contacts were either people with whom the researchers have previously worked or were people who the researchers knew might be interested in the study (based on professional contacts). When known contacts were not available, the researcher identified gatekeepers based on their expected access to participants. For example, academic deans were contacted when studying freshman students, and program directors were contacted for targeted programs of study 
(e.g., entrepreneurship programs, international programs). In a current study, the research team has begun contacting IRB offices directly after identifying faculty volunteers for classroom studies.

Gatekeepers are typically busy administrators without the time or the training to sponsor a local IRB application and schedule participants. In most cases, the researchers asked gatekeepers to identify a campus liaison to assist in recruitment of participants and serve as a local collaborator for IRB applications.

\section{Incentives and collaboration agreements}

In addition to the incentives offered to individual participants, researchers routinely planned for site-level participation incentives, including monetary honoraria, summary reports, and raw data. Several researchers offered honoraria of a few hundred dollars to local coordinators for duties such as sponsoring IRB applications, scheduling rooms and interviews, and distributing surveys via paper or email. In many cases, researchers also offered reports in the form of both overall study summaries and institution-specific comprehensive reports to administrators at the participating institutions. In the largest studies, workshops providing an opportunity to discuss the reports with the principal investigators (PIs) were organized on the local campuses. Two researchers reported providing institutions with their own raw data and a codebook in addition to a summary report.

\section{Recruiting participants}

To recruit participants, most of the researchers relied on local contacts. Student recruitment was either done in class or electronically via emails. A few studies used a census approach to reach all members of a given engineering program, but faculty and administrator recruitment was typically handled by the researcher providing a list of names and/or characteristics (e.g., department chairs, gateway course instructors) for the local coordinator to recruit and schedule. Several recommended strategies for recruiting participants were identified. First, recruitment of knowledgeable and influential local liaisons is key to facilitating paperwork and recruiting participants. Administrators internal to the institution typically have more influence in encouraging participation by their endorsement of the study; endorsements by professional societies can supplement such local endorsements. Second, researchers provided assistance to the local liaison in the recruitment and IRB process, for example by completing IRB paperwork and drafting invitation emails. Third, many researchers used incentives such as gift cards for participants, and they prominently advertised these in recruitment emails. However, in the researchers' experience, this was less successful at some elite or private institutions, where faculty participants and site coordinators are more likely to never claim incentives (by submitting consultant paperwork) or request to donate the incentive to a student organization. Lastly, some employed a rolling recruitment process in which additional invitations were used to meet the targeted response rate. In random samples, replacement of sites that declined to participate in a study was done through additional random sampling from the target population. 


\section{IRB Application Management}

Obtaining IRB for human subjects research is a mandatory first step for conducting most education research. However, the actual IRB approval process is often minimally mentioned in publications reporting findings of large multi-site studies. For all of the studies included here, the researchers first secured IRB approval from their home institution, whether or not data was to be collected there. Depending on the extent of the research, some institutions' IRB offices deferred to the researchers' home institution as the governing IRB office, and this decision was documented and included in study records. In one study, the recruited faculty at each institution were asked to verify with their local IRB and sign agreement forms provided by researcher's IRB office indicating that they had consulted with their IRB about the nature of the study before proceeding with data collection. In another, after recruiting faculty members (one at each institution) for classroom studies, the researcher contacted IRB offices directly to ask what type of review is required since no one at the institution was "engaged" in the research by analyzing data or securing informed consent. It was more common for IRB offices to request a full application submitted by a PI at the each institution being sought for participation, which is one of the main reasons that local contacts and local coordinators were recruited and compensated for their time in many studies. However, in most cases the researchers completed the various IRB forms for the different institutions and completed additional institution-specific IRB training as required.

It is also important to note that due to changing federal regulations as well as regional and local policies, IRB human subjects approval processes can be different from institution to institution and can change as policies change.

\section{Response rate}

Low response rate is a major concern in large multi-site studies. Several strategies pertaining to survey design, survey administration and endorsement of the study were recommended in the responses for maximizing individual response rates. First, in the case of survey design, the researchers recommended the use of short surveys (i.e., less than 10 minutes) to achieve targeted response rates. In addition, paper-based surveys were recommended over electronic versions, particularly for students, although this required scanning or manual entry of the responses. Such approaches were thus more costly than web-based approaches, and were not necessarily feasible in studies involving large numbers of institutions, programs, or participants. Second, for survey administration, the researchers often recommended administering student surveys during class time as an effective strategy when a census of students was not required by the research design. Endorsement of the study from instructors, deans and relevant engineering professional societies emerged as a common strategy among the responses. Following best practices in recruitment procedures, for example, using multiple, personal contacts over a period of time, was mentioned as necessary for large scale studies. Having the recruitment email coming from a respectable individual and known to the respondents at the school helped to increase response rate as well as individual participant incentives. Statistical adjustments for low response rates were commonly used in survey research, but these required that researchers had complete information on the target population (e.g., gender, discipline) to develop weights that correct for under- or overrepresentation of particular groups in a given population. 


\section{Discussion and Conclusion}

Although multi-institution engineering education studies are considered particularly generalizable and transferable, there is little opportunity for researchers to learn about how to successfully design and execute these studies. We've collaborated on this paper to compare past experiences and compile advice on several aspects of multi-institution studies. Selection of research sites is typically based on a sampling frame that considers diversity in institution types, student or faculty populations, engineering disciplines, geography and other considerations. However, we narrowed initial lists using existing contacts who could assist with IRB paperwork and access to participants. When known contacts were not available, we contacted gatekeepers who were administrators overseeing relevant units. These administrators were helpful in providing access and endorsing the studies to increase response rates, and they typically designated other staff to serve as local coordinators to assist with IRB paperwork, recruiting and scheduling. Among the incentives offered to encourage institutions to participate were reimbursements to engineering schools, honoraria for local coordinators, cash or gift cards for individual participants, reports summarizing study findings overall or local results specifically, meetings to discuss the results, and providing institutions with their raw data at the end of the study. We typically relied on local contacts to recruit participants, but we provided desired characteristics and drafted recruiting materials. Response rates were maximized through incentives, short surveys, paper surveys administered during class time, and endorsement by faculty or administrators as appropriate to the focus of the study. IRB human subjects approval is an important and time-consuming responsibility of multi-institution researchers. Smaller-scale studies, e.g., administering student surveys in classes, may be able to negotiate deferral to the investigators' IRB as the governing office, but this decision must be documented. In many cases, full IRB applications with a local PI are still most common. Here, we typically prepare IRB forms for the local coordinator to submit as PI.

In general, planning ahead and in detail is critical to the success of multi-site studies. Depending on the nature of the study, securing the participation of, and successfully collaborating with, multiple institutions may require between six months and a year, depending on the size of the sample and the complexity of the study. Multiple contacts may be required to explain study procedures to different gatekeepers and to negotiate access and time frames. Provision of summary reports and data is also a significant commitment that must be considered as the time frame for the study is developed. The duration and intensity of the process, however, pays off in extensive datasets that yield rich data that can be analyzed in multiple ways to answer pressing questions. 


\section{References}

1. Zhu, J. and M.F. Cox, Epistemological Development Profiles of Chinese Engineering Doctoral Students in US Institutions: An Application of Perry's Theory. Journal of Engineering Education, 2015. 104(3): p. 345-362.

2. Kamphorst, J.C., et al., Explaining Academic Success in Engineering Degree Programs: Do Female and Male Students Differ? Journal of Engineering Education, 2015. 104(2): p. 189-211.

3. Litchfield, K. and A. Javernick-Will, “I Am an Engineer AND”: A Mixed Methods Study of Socially Engaged Engineers. Journal of Engineering Education, 2015. 104(4): p. 393416.

4. Litchfield, K., A. Javernick-Will, and A. Maul, Technical and Professional Skills of Engineers Involved and Not Involved in Engineering Service. Journal of Engineering Education, 2016. 105(1): p. 70-92.

5. Moore, T.J., et al., Changes in Faculty Members' Instructional Beliefs while Implementing Model-Eliciting Activities. Journal of Engineering Education, 2015. 104(3): p. 279-302.

6. $\quad$ Ro, H.K., et al., Validity of the Contextual Competence Scale for Engineering Students. Journal of Engineering Education, 2015. 104(1): p. 35-54.

7. Besterfield-Sacre, M., et al., Assessing the Spectrum of International Undergraduate Engineering Educational Experiences, in 2016 ASEE Annual Conference and Exposition. 2016: New Orleans, LA.

8. $\quad$ Nguyen, K.A., et al., Measuring Student Response to Instructional Practices (StRIP) in Traditional and Active Classrooms, in American Society for Engineering Education Annual Conference and Exposition. 2016: New Orleans, LA.

9. Harding, T.S., D.D. Carpenter, and C.J. Finelli, An exploratory investigation of the ethical behavior of engineering undergraduates. Journal of Engineering Education, 2012. 101(2): p. 346.

10. Holsapple, M.A., et al., Framing faculty and student discrepancies in engineering ethics education delivery. Journal of Engineering Education, 2012. 101(2): p. 169.

11. Burt, B.A., et al., Out-of-classroom experiences: Bridging the disconnect between the classroom, the engineering workforce, and ethical development. International Journal of Engineering Education, 2013. 29(3): p. 714-725.

12. Finelli, C.J., et al., An Assessment of Engineering Students' Curricular and CoCurricular Experiences and Their Ethical Development. Journal of Engineering Education, 2012. 101(3): p. 469-494.

13. Besterfield-Sacre, M.E., et al., Essential Factors Related To Entrepreneurial Knowledge in the Engineering Curriculum, in ASEE Annual Conference and Exposition. 2012: San Antonio, TX.

14. Besterfield-Sacre, M., et al., Faculty and Student Perceptions of the Content of Entrepreneurship Courses in Engineering Education. Advances in Engineering Education, 2016. 5(1): p. n1.

15. Besterfield-Sacre, M., et al., Changing engineering education: Views of US faculty, chairs, and deans. Journal of Engineering Education, 2014. 103(2): p. 193-219. 
16. Crede, E. and M. Borrego, Undergraduate engineering student perceptions of graduate school and the decision to enroll, in American Society for Engineering Education Annual Conference. 2011: Vancouver, BC, Canada.

17. Crede, E. and M. Borrego, Understanding retention in US graduate programs by student nationality. Studies in Higher Education, 2013. 39(9): p. 1599-1616.

18. Borrego, M., et al., Influence of Engineering Instructors' Teaching and Learning Beliefs on Pedagogies in Engineering Science Courses. International Journal of Engineering Education, 2013. 29(6): p. 1456-1471.

19. Boden, D., M. Borrego, and L.K. Newswander, Student socialization in interdisciplinary doctoral education. Higher Education, 2011. 62(6): p. 741-755.

20. Lattuca, L.R., P.T. Terenzini, and J.F. Volkwein, Engineering Change: Findings from a Study of the Impact of EC2000, Final Report. 2006, ABET, Inc: Baltimore, MD.

21. Lattuca, L.R., L.C. Strauss, and J.F. Volkwein, Getting in sync: Faculty and employer perceptions from the national study of EC2000. International Journal of Engineering Education, 2007. 22(3): p. 460.

22. Lattuca, L.R., et al., 2020 Vision: Progress in Preparing the Engineer of the Future. 2014, Author: Ann Arbor, MI.

23. Lattuca, L.R., I. Bergom, and D.B. Knight, Professional development, departmental contexts, and use of instructional strategies. Journal of Engineering Education, 2014. 103(4): p. 549-572.

24. Passow, H.J., et al., Factors influencing engineering students' decisions to cheat by type of assessment. Research in Higher Education, 2006. 47(6): p. 643-684.

25. Besterfield-Sacre, M., et al., Gender and ethnicity differences in freshmen engineering student attitudes: A cross-institutional study. Journal of engineering Education, 2001. 90(4): p. 477. 